\title{
New African species in the Drosophila obscura species group: genetic variation, differentiation and evolution
}

\author{
Marie Louise Cariou,* \\ Daniel Lachaise, \\ Leonidas Tsacas, ${ }^{*}$ \\ John Sourdis, $\dagger$ \\ Costas Krimbas $†$ and \\ Michael Ashburner
}

\author{
* Laboratoire de Biologie et Génétique Évolutives \\ 91198, Gif-sur-Yvette, Cedex France. \\ $\uparrow$ Department of Genetics, Agricultural College of \\ Athens, Greece. \\ $\ddagger$ University of Cambridge, Department of Genetics, \\ Downing Street, Cambridge CB2 3EH, U.K.
}

The Drosophila obscura species group was known in the Afrotropical region from a single species, $D$. microlabis. This species was recently rediscovered in Kenya in addition to the discovery of three new obscura group species: $D$. kitumensis, $D$. cariouae and $D$. krimbasi. The patterns of allozyme variation in two African species, $D$. microlabis and $D$. kitumensis is compared to that of nine species of the obscura group. Genetic distances have been estimated from allelic frequencies at 35 loci and phylogenies inferred by methods assuming both constant as well as variable evolutionary rates. $D$. microlabis and $D$. kitumensis are evolutionary related and close to the Palearctic $D$. tristis and $D$. ambigua even if relatively distant. The data support Lakovaara and Saura's hypothesis recognising three species subgroups within the obscura group. In addition, we propose a fourth one for the new African species, the microlabis species subgroup.

\section{INTRODUCTION}

The Drosophila obscura species group is widely distributed in the Palearctic and Nearctic regions. In the Afrotropical region it was known from a single species, D. microlabis Seguy, described in 1938 (Seguy, 1938) from a single male collected from Kenya (Marakwet, on the Elgeyo Escarpment) by the Omo expedition (Arambourg et al., 1935). More recently, Tsacas (1974) confirmed that this species was a member of the obscura group and assigned it to the obscura species subgroup. The Museum of Paris specimen remained, for half a century, the sole indication of the presence of the obscura species group in the Afrotropical region.

During a recent field investigation in Kenya (D. Lachaise, M. L. Cariou and M. Ashburner, Sept. 1984) D. microlabis was rediscovered from Mt Elgon, on the west side of the Kenya (or Gregory) Rift Valley. In addition, three new obscura group species were discovered: one also from Mt Elgon, D. kitumensis Tsacas and two sympatric species from Mt Kenya on the East side of the Rift Valley, $D$. krimbasi Tsacas and $D$. cariouae Tsacas. All of these species have been recently described (Tsacas et al., 1985). Thus, there are at least four species of the obscura species group in Kenya, and we suspect that many more may occur in the East African highlands. All these species were collected at high altitudes, above 2000 meters. Neotropical species of the obscura species group (affinis subgroup), D. azteca and D. tolteca as well as the Neotropical populations of $D$. pseudoobscura (Throckmorton, 1975) are also found only at high altitudes. Thus, there is strong presumption that the obscura species group, which is basically Holarctic in its distribution (Wheeler, 1981), has extended its geographic range over both the Afrotropical and Neotropical regions but only in the temperate climatic conditions of mountains.

With the new African species the obscura species group now includes 35 species. Although this is one of the most extensively species groups of Drosophila that have been studied (see, BuzzatiTraverso and Scossiroli, 1955; Lakovaara and Saura, 1982 for a review) many questions remain concerning the relationships between the species. The division of the group into two species subgroups is itself still questionable. On the basis of morphological and allozymic characters, the obscura group has long been subdivided into two 
species subgroups: the affinis subgroup, with nine exclusively Nearctic species, and the widespread Palearctic species $D$. helvetica-the obscura subgroup, which includes 14 Palearctic species and seven Nearctic species. Several of the Palearctic species are widespread, D. subobscura, D. obscura, $D$. ambigua and D. bifasciata, which probably is the most widely distributed species within the group. Lakovaara and Saura (1982) have argued that the division of the obscura group into two subgroups is not a "natural one" and suggested dividing the obscura species subgroup into two lineages: the pseudoobscura species subgroup and the obscura species subgroup to include the Nearctic and Palearctic species, respectively.

In the present work, we have the compared patterns of allozyme variation in two African species, D. microlabis and D. kitumensis, with that of nine species of the obscura group (sensu lato). Genetic distances have been estimated on the basis of allelic frequencies at 35 loci, and phylogenies have been inferred by methods assuming both constant as well as variable evolutionary rates. The data support Lakovaara and Saura's hypothesis. In addition we propose a fourth species subgroup for the new African species, the microlabis species subgroup.

\section{MATERIAL AND METHODS}

\section{The African species and their habitats}

Drosophila cariouae and D. krimbasi were both collected from Mt Kenya (2470 m) at Main Gate of Mt Kenya National Park, by banana traps placed above a domestic rubbish dump just behind gate hut. The former species was also collected by banana trap in Podocarpus/bamboo forest about $0.5 \mathrm{~km}$ from the Main Gate. One strain of $D$. cariouae failed to establish successfully after the first generation, while $D$. krimbasi was described from a single male. Therefore only two of the four African species could be studied, D. microlabis and D. kitumensis.

D. microlabis was collected in banana traps and by sweeping at Mt Elgon Lodge $(2200 \mathrm{~m})$, $1.5 \mathrm{~km}$ from Main Gate of Mt Elgon National Park (fig. 1). Most traps and sweep sites were in a domestic habitat, i.e., garden with grass and shrubs but with small fruit dump (tomatoes). In spite of an intensive search, the species was not collected in wild habitats in the Mt Elgon slope forest at higher elevations. On Mt Elgon the collection sites followed the main track from the Main Gate of the National Park $(2260 \mathrm{~m})$ to the moorland
$(4200 \mathrm{~m})$ below Koitoboss peak. This track runs between the Komothon River (to the north) and the Kassowai River (to the south). It is generally the same region as was covered by the Omo Expedition. D. microlabis was abundant at Mt Elgon lodge and is apparently a widely distributed species, it probably ranges from Mt Elgon to the Elgeyo Escarpment where it was collected in 1935. The species can easily be grown on standard cornflour culture medium and a mass culture was established from 30 wild caught inseminated females.

$D$. kitumensis was collected from the area in front of the Kitum Cave $(2500 \mathrm{~m})$ in submontane forest with Diospyros abyssinica below the Podocarpus zone, $5 \mathrm{~km}$ from Main Gate of the Mt Elgon National Park (fig. 1). Kitum Cave is a large and deep excavation, much visited by elephants and buffaloes, located in valley of Rongai River. The area immediately in front of the cave is very disturbed by animals and is a jumble of rocks dominated by Discopodium penninervium (Hochst) (Solanaceae), the climbing plant Stephania abyssinica (Dillon and Rich) Wolp. var. tomentella (oliv.) Diels, Urtica massaica Mildbr. and with much dead/rotting wood. The entire valley in front of the cave was wet and cooled by air from the cave and was obviously different in its flora from the surrounding forest and from other cave valleys of the East slope of Mt Elgon (Makingeny Cave, Chepnyalil Cave) where D. kitumensis was not observed.

D. Kitumensis was only found at the east edge of Cave entrance, in a sap rot on a large tree, Ekebergia rueppeliana (Fresen) A. R. (Meliaceae). Adult flies were associated with this sap rot and only $D$. kitumensis was collected there by sweeping. This quite soft and wet substrate contained larvae, presumably of the same species; it is likely that the sap rot of E. rueppeliana is the breeding site of $D$. kitumensis. Similar natural breeding sites, sap and slime fluxes of trees (Oak, sycamore, willow, fir and elm) have been reported for $D$. pseudoobscura, D. persimilis (Carson, 1951), D. ambigua (Prevosti, 1959), D. obscura (Gordon, 1942) and D. subobscura (Carson et al. 1985).

D. kitumensis is difficult to breed, nevertheless, a strain was established from 13 wild-caught females and kept on standard culture medium.

\section{Other species}

For D. subobscura we studied a natural population from the French Pyrénées (Riberot locality), a strain from Crete (Greece), another from Switzerland and two standard strains, Küstnacht 

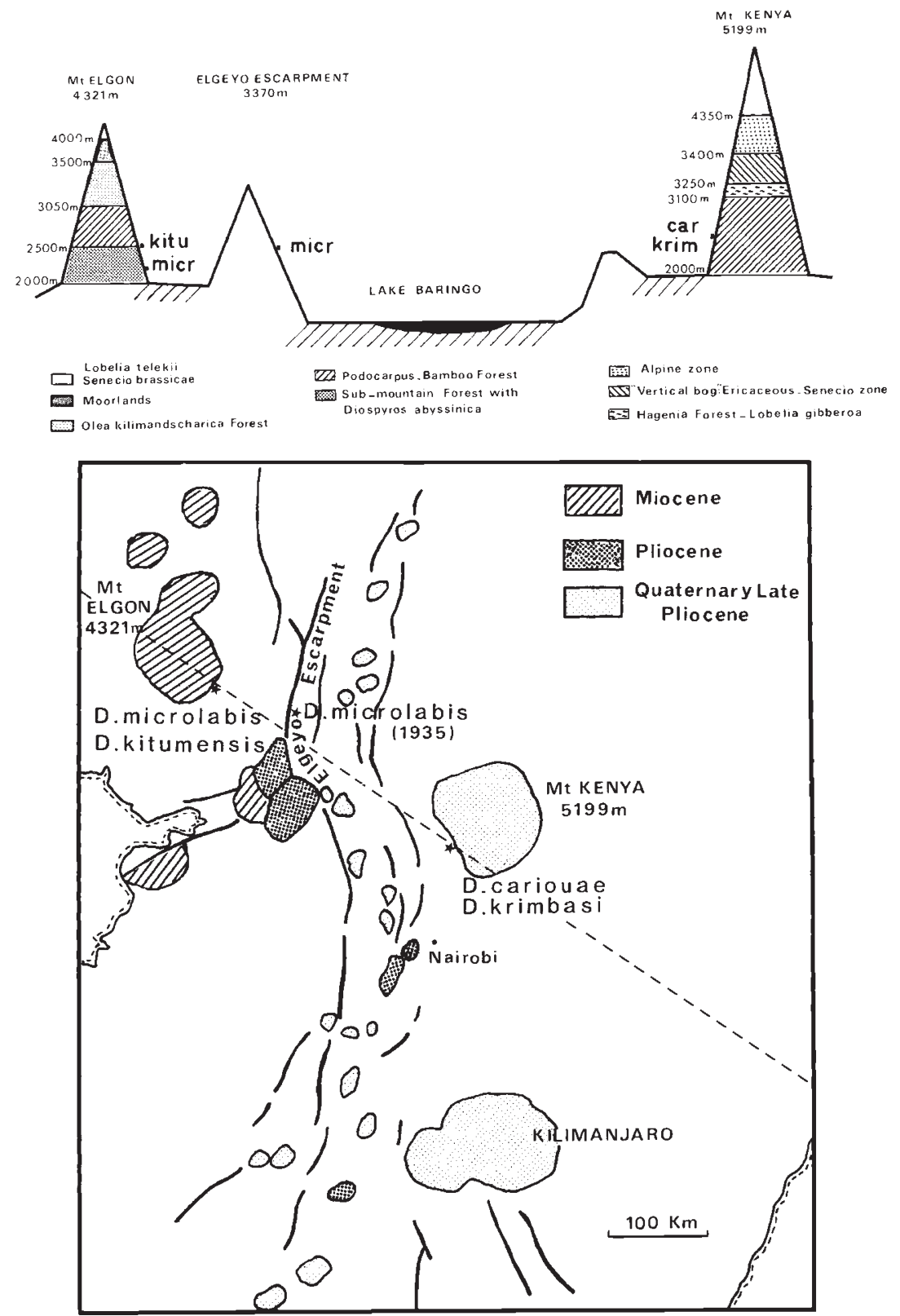

Figure 1 Localities of the four African species of the Drosophila obscura species group in the highland forests on the eastern and western flanks of the Kenya (Gregory) Rift Valley (Altitudinal zonation of Mt Elgon and Mt Kenya after data in Schnell, 1977; Hamilton and Perrot, 1981; Geological map summarising the volcanic history of the Kenya Rift after King and Chapman, 1972).

(Lankinen and Pinsker, 1977) and Chcu homogeneous for most enzyme loci.

Two natural populations collected in valleys in the French Pyrénées (Riberot and Estours) and one strain from Switzerland represented $D$. obscura. One population of $D$. helvetica from Gif (France) was used. We also analysed some labora- tory stocks for between species comparisons: three for $D$. bifasciata from Norway (strain 24), Italy (Pavia) (strain 25) and U.S.S.R. (Alma Ata) and only one for the following species: D. tristis (Switzerland), D. ambigua (Mt Parnes, Greece), $D$. madeirensis (Madeira Island), D. guanche (Canary Islands) and D. pseudoobscura (USA). 


\section{Genetic assays}

Electrophoresis was predominantly carried out on starch gel following the general procedures of Shaw and Prasad (1970) and Ayala et al. (1972) with some modifications. The $\alpha$-amylase was analysed using a 5 per cent acrylamide gel as described in Daïnou et al. (1987).

Electrophoresis was performed on adult flies except for Est 1, Lap1 and Acph2 (third instar larvae) and Lap2 (pupae). Allozymes were designated by their electrophoretic mobility relative to that of the most common allozyme of $D$. subobscura, numbered 100 . For each locus, 30 to 85 individuals were tested for $D$. microlabis, $D$. kitumensis and the natural populations of $D$. subobscura and $D$. obscura. The laboratory strains were studied only as a reference for the between species comparisons and fewer individuals were scored, from 15 to 25 .

Four kinds of Nei's genetic distances $\left(D_{1}\right)$ have been used (the usual standard, $D_{1 \text { st }}$, another when only the most frequent allele was considered, $D_{m}$, and two others) as well as two kinds of another distance, $D_{2}$ (depending on whether data of the most common allele or all alleles were used in each locus), all described in Krimbas and Sourdis (1987).

Four different methods for constructing trees were used: UPGMA (Sneath and Sokal, 1973), Farris (1972), Fitch and Margoliash (1967) and a modified version of Farris' method (Tateno et al., 1982). The three last methods were further modified by us in such a way that trees with negative distances were rejected (Sourdis and Krimbas, 1987).

Concordance of reconstructed trees with the original data could eventually indicate fidelity to the "real" phylogeny. The measure used was the sum of the squares of the differences in distances between the reconstructed and the original (experimental) distances. These distances have been normalised in every matrix to one in order to get comparable data.

\section{RESULTS}

The most common allozymes of the 35 putative loci screened in the 19 populations and species studied are presented in table 1. Variation is great between species and none of the 35 loci is strictly monomorphic. Polymorphic loci are those already known to be polymorphic in the Drosophila obscura group. The total number of alleles detected is 180 , some of these are rare and only detected in recently collected natural populations. The Amy locus appears to be highly variable, with 14 allozymes identified.

From the electrophoretic data, it follows that the two African species, D. microlabis and $D$. kitumensis are both clearly distinguished from the other species of the obscura group by different alleles fixed at three loci, Pgm, Gdh and Amy. In addition they only share rare alleles with one or two species at three more loci, Mdh, Pgi and Est6. Of the 35 loci analysed, eight are diagnostic between D. microlabis and D. kitumensis: $6 P g d$, $X d h, A o, O d h, A c p h 1$, Acph2, Alph and Lap1.

Estimates of heterozygosity and percentage of variable loci are given in table 2 . The percentage of polymorphic loci ranges from 3 per cent (laboratory strains) to 43 per cent (D. microlabis) with a mean at 2011. Drosophila kitumensis is polymorphic at 26 per cent of its loci. The mean number of alleles per polymorphic locus is 2 and the mean number of alleles per locus per species is respectively 1.46 for $D$. microlabis and 1.26 for $D$. kitumensis. The mean expected heterozygosity for D. microlabis $(0.094)$ and D. kitumensis $(0.067)$ comes within the range of variation found for other species of the obscura group (table 2).

$D_{2}\left(D_{2}\right.$ polymorphic) and Nei's standard $\left(D_{1 \mathrm{st}}\right)$ genetic distances based on allele frequencies are presented in table 3 . The genetic distances within the same species (D. subobscura, D. obscura and D. bifasciata) are very small (from 0.004 to 0.11 ) indicating that strong differentiation does not exist between either local or geographically distant populations of these species. This is in good agreement with previous studies (Lakovaara and Saura, 1971; Lakovaara et al., 1976; Loukas et al., 1979; Pinsker and Buruga, 1982).

Extensive isozyme divergence among species is further indicated by the great magnitude of genetic distances. Nei's distance ranges from $0 \cdot 269$ to $2 \cdot 416$ and $D_{2 p}$ from $0 \cdot 105$ to $0 \cdot 571$. The two least divergent species are the African $D$. microlabis and $D$. kitumensis, they are genetically closer to one another than any other couple of species known to have some degree of relatedness on the basis of other critera, e.g. D. tristis and D. ambigua $\left(D_{1 \mathrm{st}}=0.404\right)$, or the triplet $D$. subobscura, $D$. guanche, D. madeirensis $\left(0.522<D_{1 \mathrm{st}}<0.838\right)$.

Very high distances are obtained when $D$. helvetica is paired with any other species; the highest value is between this species and $D$. kitumensis $\left(D_{1 \mathrm{st}}=2 \cdot 416\right)$.

Different trees can be constructed using either, or both, different measurements of genetic distance 


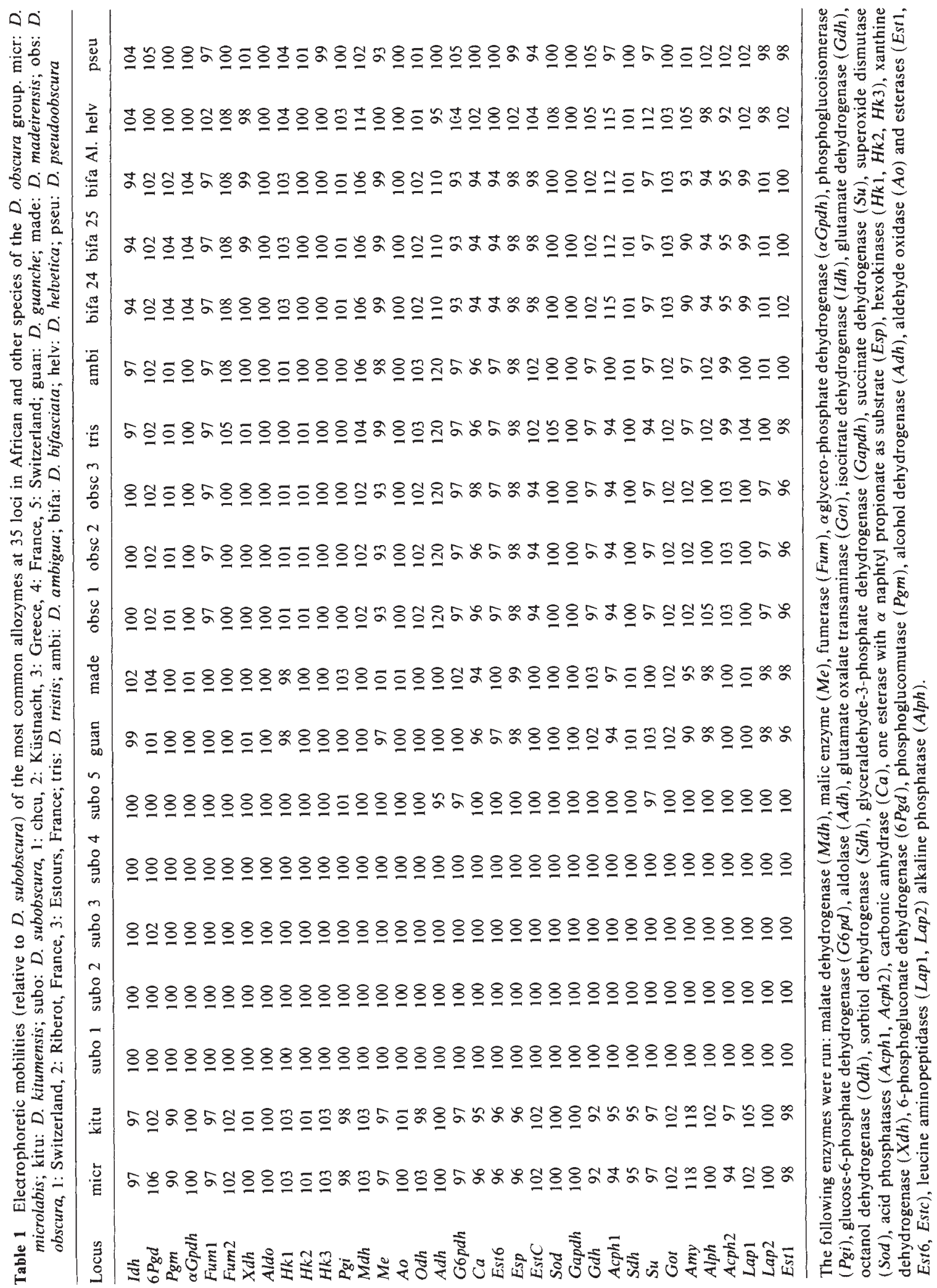


Table 2 Amount of genetic varation in D. microlabis and D. kitumensis compared with different species analysed in our work and published data. The total number of loci studied is given within brackets

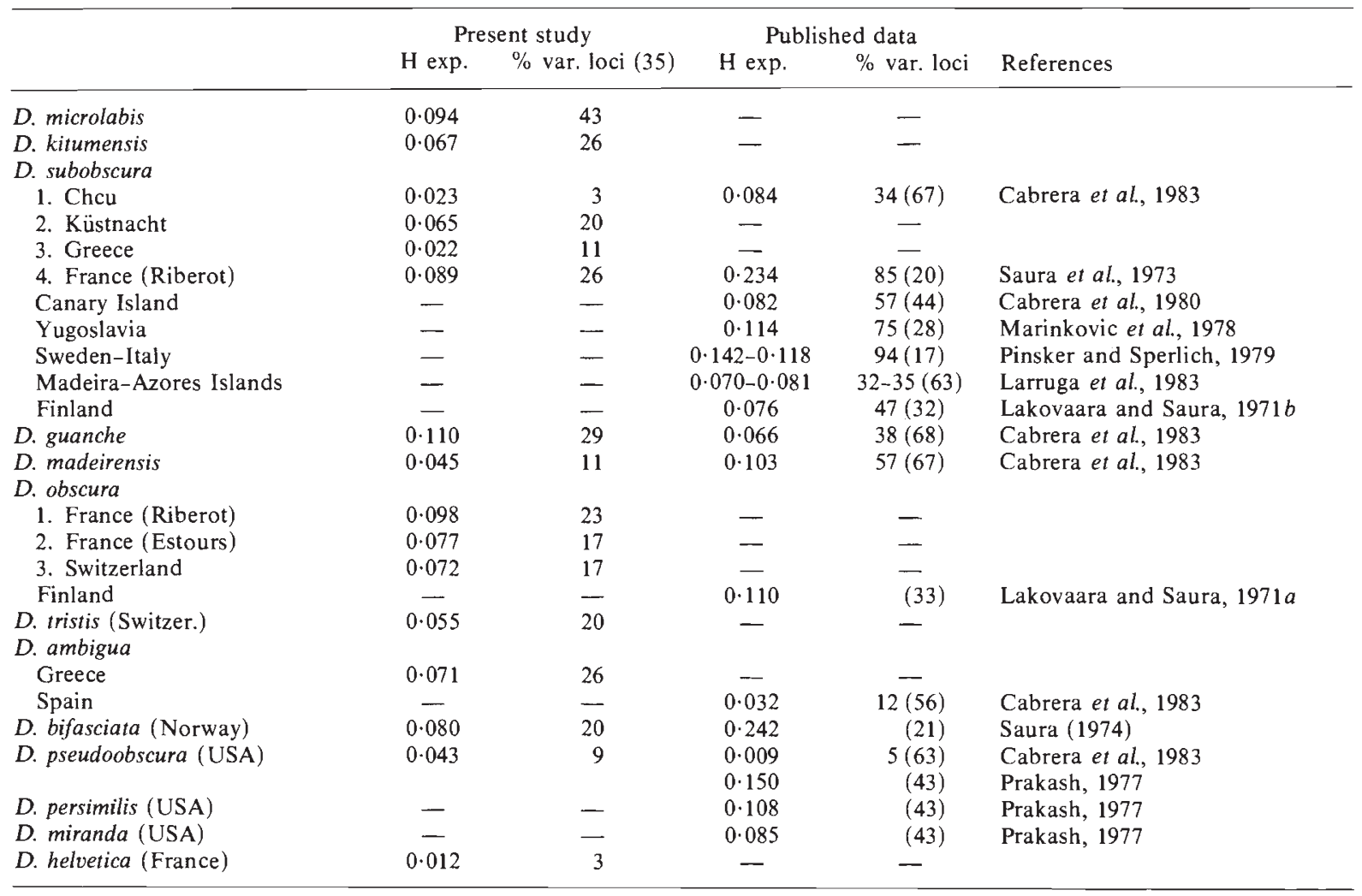

or different algorithms. One way of evaluating different trees is by determining the tree that best represents the data, although the "best fit" may not necessarily be the best hypothesis of evolutionary relationships. Therefore we have used several other criteria based on extraneous information concerning group taxonomy to judge tree reliability; these were, whether or not different populations of the same species clustered, the relative positions of $D$. madeirensis and $D$. guanche close to D. subobscura (Krimbas and Loukas, 1984) and the relative closeness of $D$. tristis and $D$. ambigua (Lakovaara et al., 1972; Lakovaara and Keränen, 1980).

Independently of branch lengths, the alternative topologies depicted in fig. 2 differ in the hatched zone, that is in the branching of D. microlabis and $D$. kitumensis and, D. tristis, D. ambigua and $D$. pseudoobscura. The trees are ranked according to their goodness-of-fit. They all satisfy the reliability criteria, except number 3 where $D$. tristis and $D$. ambigua are separated, and number 6 , which is rejected because $D$. madeirensis and $D$. guanche do not cluster with $D$. subobscura.
It is worth emphasising that the five best trees all position the African species close to one another and quite close to the European species-pair, $D$. tristis-D. ambigua, and also to some extent to the American D. pseudoobscura.

The unrooted tree obtained from $D_{2}$ polymorphic distance and the modified Farris clustering has the best fit (fig. 3). A phylogenetic interpretation of this unrooted tree is reasonably consistent with the biochemical and chromosomal affinities previously inferred regarding the position of the Palearctic species of the obscura group (see Lakovaara and Saura, 1982, for a review). D. subobscura is close to its two endemic relatives $D$. guanche and $D$. madeirensis although the relative position of the these species differs from that found by Cabrera et al. (1983) and Loukas et al. (1984). This could result from the use of different sets of loci, or the use here of a better method for tree construction, but may also be indicative of ambiguity regarding their relative genetic divergence.

D. subobscura is significantly distant from $D$. obscura, D. tristis and D. ambigua are obviously 


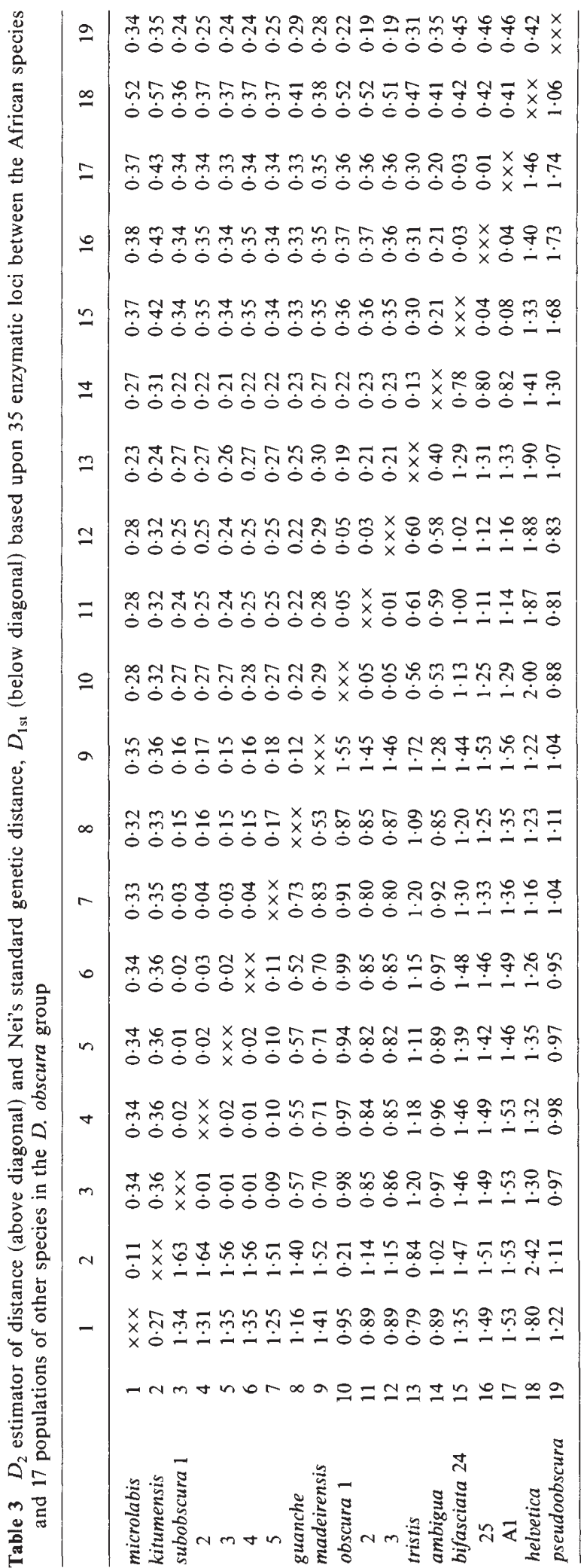



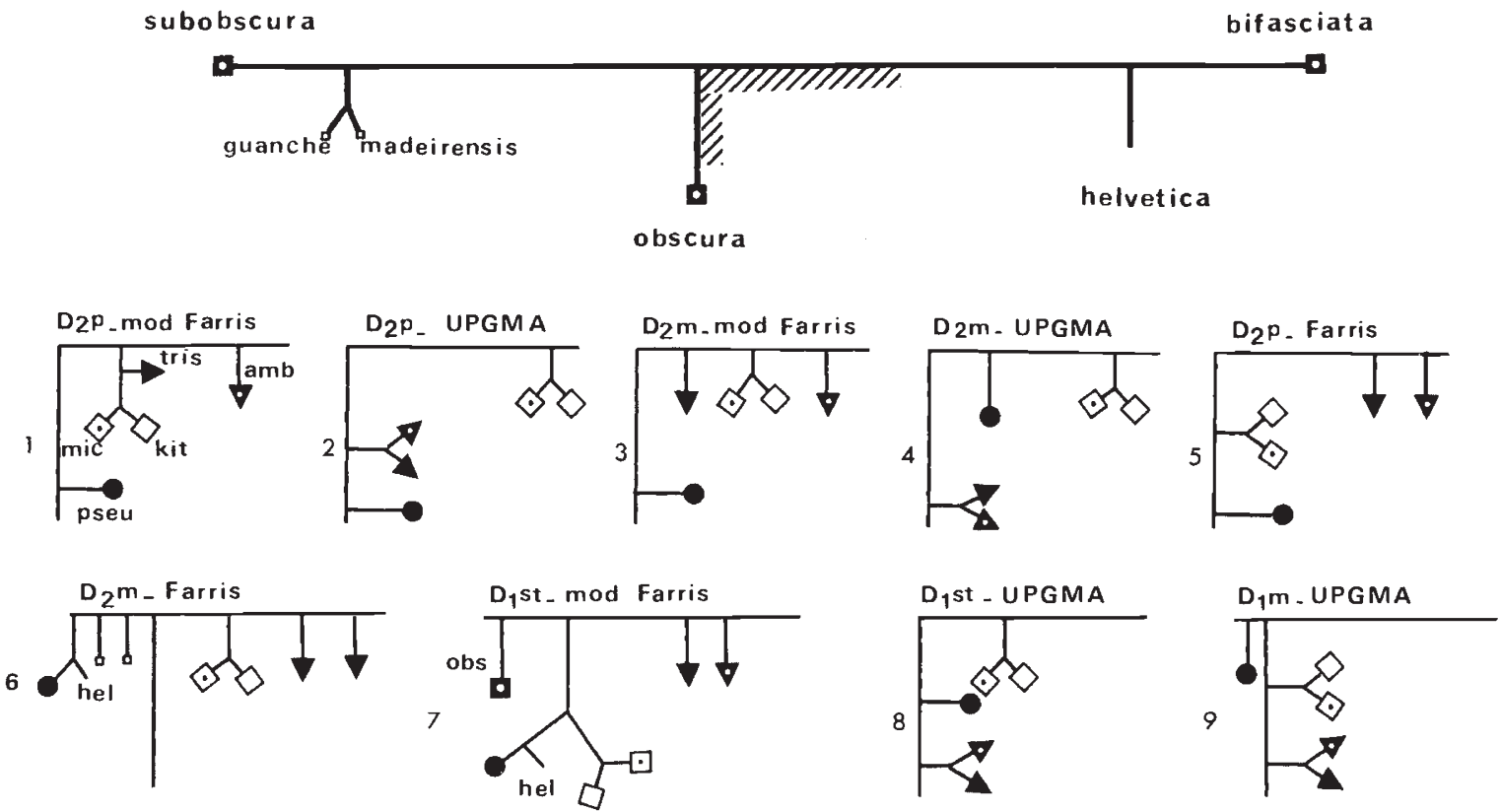

Figure 2 Alternative topologies derived using different algorithms using $D_{2}$ and Nei's genetic distances depict different relationships between species within the hatched zone. The trees are numbered according to their goodness-of-fit measures. mic: $D$. microlabis, kit: D. kitumensis, tris: D. tristis, amb: D. ambigua, obs: D. obscura, pseu: D. pseudoobscura, hel: D. helvetica.

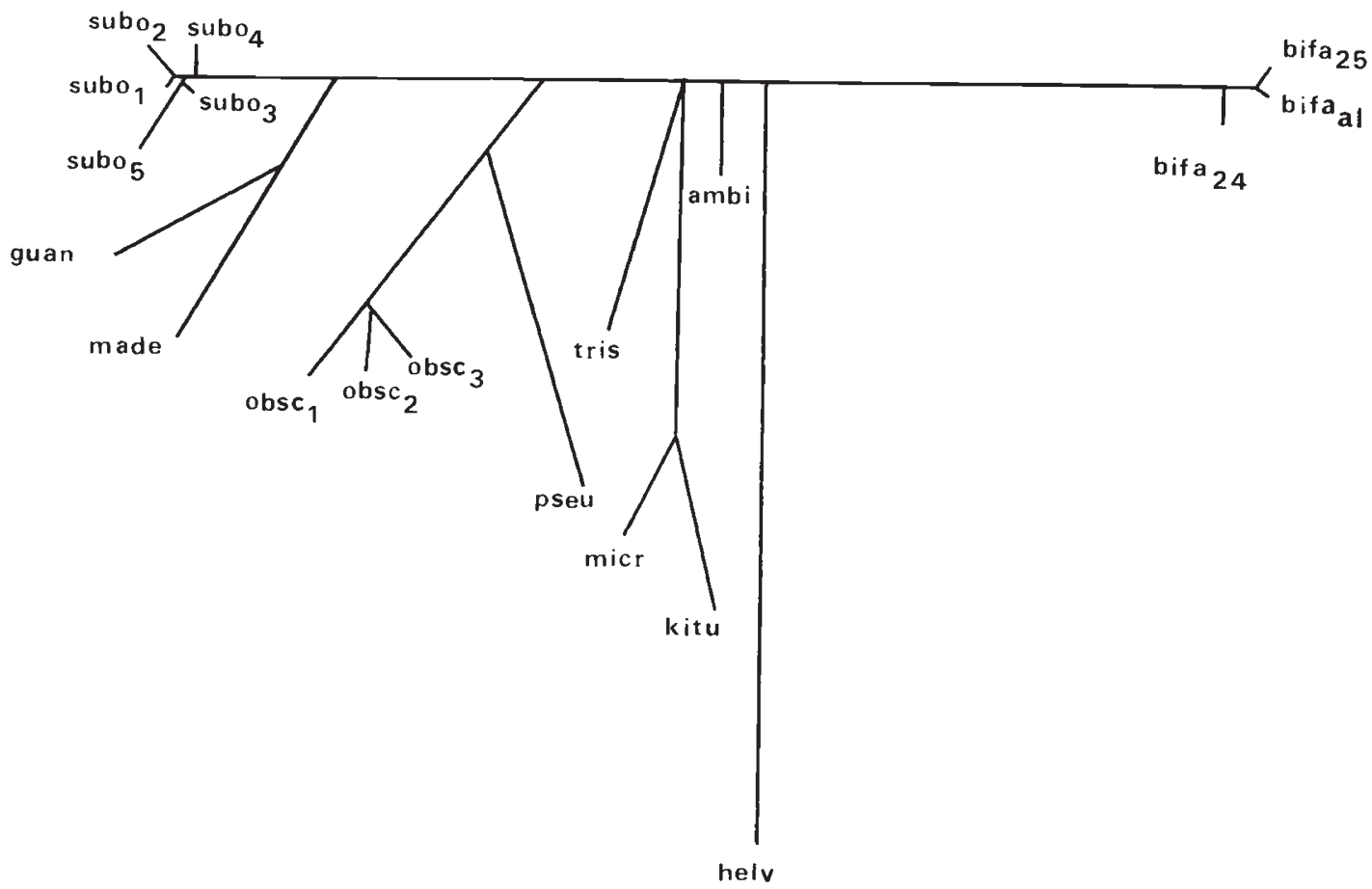

Figure 3 Evolutionary relationships of the African species to others of the Drosophila obscura group as deduced from allozyme divergences. The unrooted tree is constructed by the modified Farris method clustering of $D_{2}$ polymorphic distances. 
here related species. D. bifasciata appears genetically quite distinct from $D$. subobscura and the obscura relatives ( $D$. obscura, $D$. tristis, $D$. ambigua). D. helvetica is the most distant species and is not appreciably related to any of those analysed here.

The position of $D$. pseudoobscura is more problematic. Lakovaara and Saura (1982) found that the Nearctic obscura subgroup species were not appreciably related to the Palearctic species or to the Nearctic affinis subgroup. Our data show that genetically, $D$. pseudoobscura is closest to $D$. obscura $\left(D_{1 \mathrm{st}}=0 \cdot 8\right)$ and is related to $D$. tristis and $D$. ambigua. The old laboratory strain of $D$. pseudoobscura used may not be representative of the species. However, Cabrera et al. (1983) also found some relatedness between $D$. pseudoobscura and $D$. ambigua. Moreover, hybridizations provide some evidence relating $D$. pseudoobscura to some Palearctic species: $D$. pseudoobscura and or $D$. persimilis crossed to either $D$. bifasciata, $D$. tristis or D. ambigua yield either sterile hybrids or pupae (Koske, 1953; Buzzati-Traverso and Scossiroli, 1955) while the European species generally produce no interspecific hybrids when crossed to one another (except $D$. subobscura $\times D$. madeirensis and $D$. madeirensis $\times D$. guanche, Krimbas et al., 1984).

\section{DISCUSSION}

The discovery in the Kenya highlands of a complex of Drosophila species belonging to the obscura group allows new insight into the evolutionary history of this group.

Of the four African obscura relatives two were found on the Eastern slope of Mt Elgon to the West of the Kenya Rift Valley and the others two on the western slope of Mt Kenya to the east of the Rift. The four species were found at similar altitudes, between 2200 and 2500 metres and the question arises whether or not these two species pairs have resulted from a vicariant event, due to the aridification of the Rift as a climatic barrier.

The Kenya (Gregory) Rift Valley is a sector of the Rift system of eastern Africa which has been marked by continuous volcanic activity throughout its history from Miocene times to the present day. The largest of the central volcanoes are on the flanks of the Rift, but whereas those to the west (e.g., Mt Elgon) are Miocene in age, those to the east (e.g., Mt Kenya) are mainly Pleistocene to Recent (King and Chapman, 1972).
Drosophila microlabis and D. kitumensis from Mt Elgon are evolutionarily related. They always branch together regardless of the genetic distance or tree-building method used. This agrees with the morphological data (fig. 4): the two species have very similar genitalia and long sex combs while both $D$. cariouae and $D$. krimbasi have short sex combs and different male genitalia (Tsacas et al., 1985). These data support the vicariance hypothesis. There are, however, two reservations, first, there is no evidence for the relatedness of $D$. cariouae and D. krimbasi; secondly, the single male assigned to a fifth African species, collected with $D$. cariouae in the Podocarpus/bamboo forest on Mt Kenya, is strikingly close in its genital morphology to $D$. kitumensis from Mt Elgon.

Regarding the relationship of these species with its non-African obscura relatives, the most distantly related species is $D$. helvetica. Although included in the affinis subgroup $D$. helvetica is clearly not closely related to any of these Nearctic species. However, a relationship of the African species and the affinis subgroup cannot be discarded. With respect to the obscura and pseudoobscura lineages $D$. microlabis and $D$. kitumensis are closer to the Palearctic D. tristis and D. ambigua than to the American D. pseudoobscura. However, the relevant genetic distances are large and any relationship is relatively distant. This conclusion is consistent with the observation that neither $D$. microlabis nor $D$. kitumensis will hybridise with any other obscura group species (all these studied in this paper and also $D$. subsilvestris have been tested) nor with each other (Tsacas et al., 1985).

Electrophoretic evidence clearly shows strong heterogeneity within what is generally admitted as the obscura subgroup. Therefore, we concur with Lakovaara and Saura (1982) in recognising three species-subgroups instead of two, in the obscura group and further propose to introduce a fourth subgroup to include the African species, the microlabis species subgroup (fig. 5).

In summary, the extent of the newly discovered African lineage in the obscura species group provides new insight into the origin and evolutionary development of the obscura species group. On the basis of a "symplesiomorphic" acrocentric X chromosome, homologous to the $\mathrm{X}$ of $D$. melanogaster, Patterson and Stone (1952) considered $D$. subobscura to be a representative of the "ancestral" lineage of the group. Assuming this, Lakovaara and Saura (1982) stated that if such a $\mathrm{X}$ chromosome were to be found in $D$. microlabis, this species might belong to an "ancestral" lineage as well. Preliminary results indime that this is not 


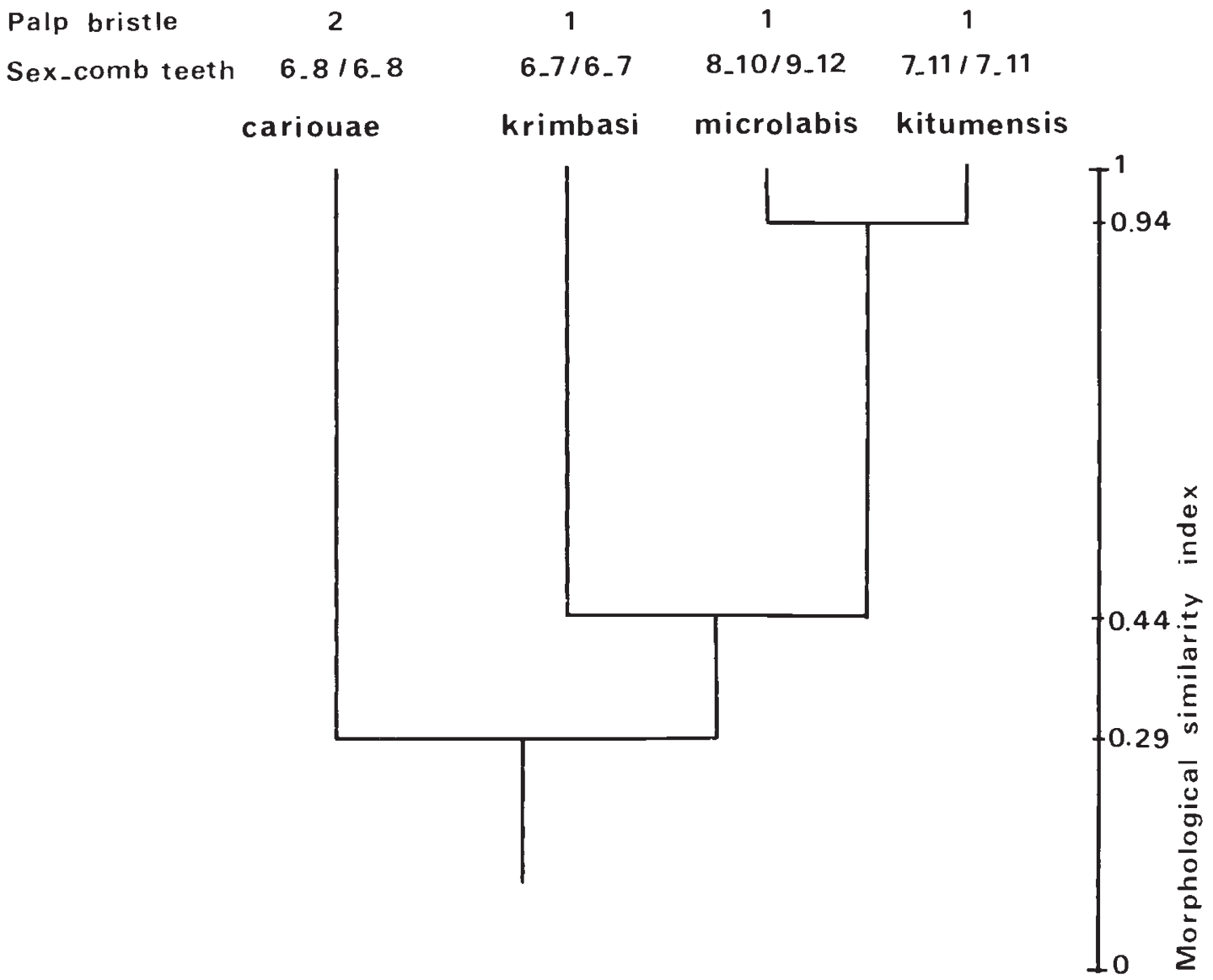

Figure 4 Cladogram (UPGMA method) based on morphological affinities between the four African species of the obscura species group. Similarity was estimated for each pair of species by the proportion of common characters on the total 17 characters considered, including sex combs and clasper combs, wing indices, oral bristles, ejaculatory bulbs and various features of both phallus and parameres.

the case (Krimbas et al., in prep.) and that the two African species have eight euchromatic arms more or less similar to those of D. ambigua, D. tristis and D. bifasciata. Also, Marinkovic et al. (1978) suggested that the American obscura subgroup species diverged from the $D$. subobscura lineage. Neither the present allozyme data nor those of Cabrera et al. (1983) support this hypothesis but rather suggest that the central taxon group might well be the obscura-tristis-ambigua lineage, because both American (D. pseudoobscura) and African species (D. microlabis and D. kitumensis) show some degree of relatedness to it. Species such as $D$. bifasciata (and to some extent $D$. helvetica) that have very large geographic ranges, from Western Europe to Japan, have also been considered to be potential evolutionary links between the obscura and the affinis subgroups (Lakovaara and Saura, 1982). Hence, the proto-obscura lineage might have been "tristis-ambigua like" or a "bifasciata like" species.

The origin of the obscura species group remains controversial, especially with respect to the chronology of the splitting events of the major lineages. In view of affinities with the melanogaster species group, Throckmorton (1975) derived the obscura species group from a primeval protomelanogaster/obscura trunk. On the basis of diversity criteria the origin of the melanogaster species group is assumed to be oriental (Bock and Wheeler, 1972; Bock, 1980; Tsacas, 1984; Lemeunier et al., 1986). A plausible scenario is to consider that from that centre of origin the protoobscura stock first split into two ancestral lineages, one of them diversifying in East Africa and the other extending to Europe, where it differentiated giving rise subsequently to both the New World pseudoobscura and affinis lineages. 


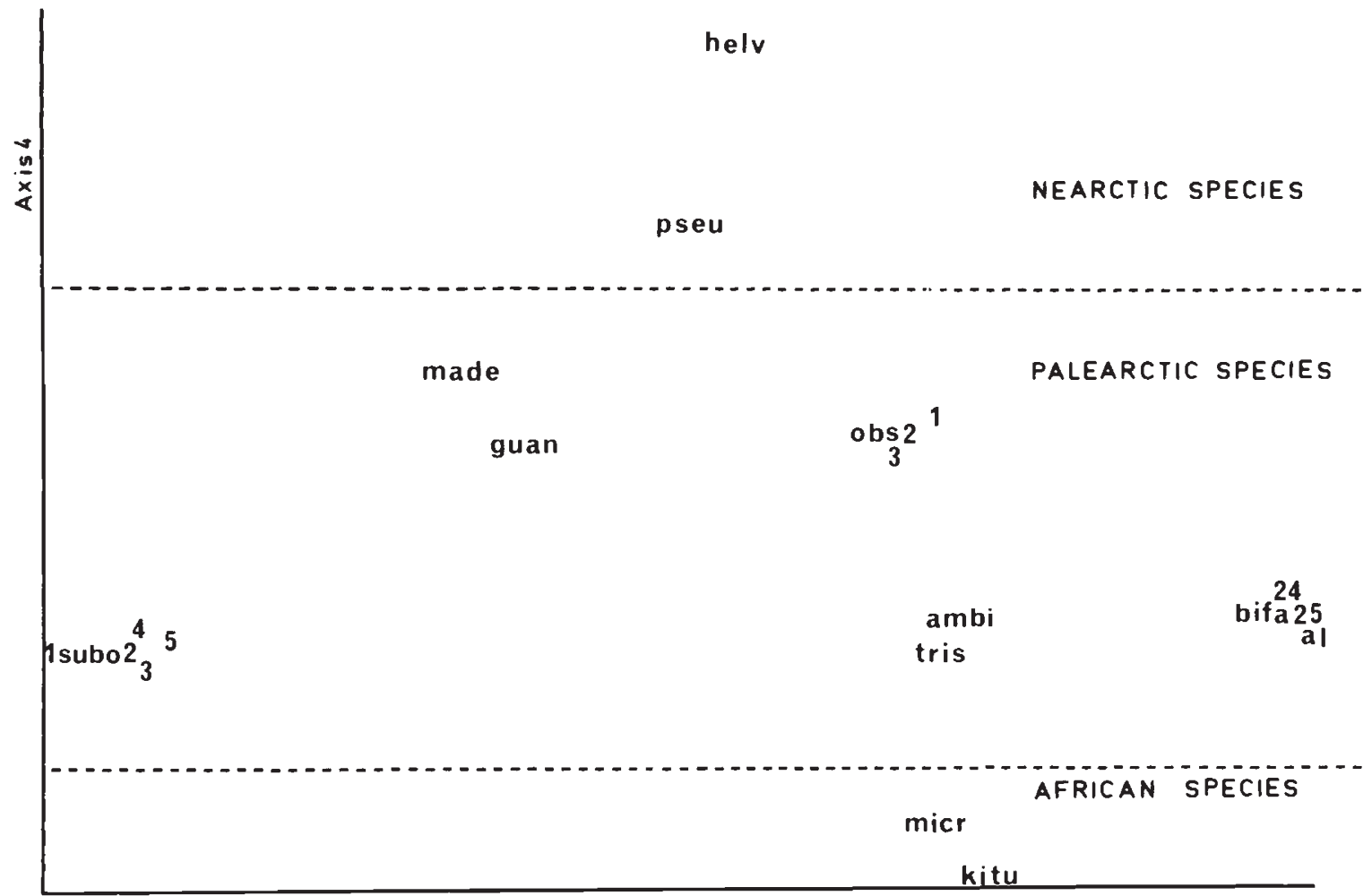

Axis 1

Figure 5 Multivariate analysis (Centered data analysis, Lefebvre, 1976) based on allele frequencies at 35 loci. Plotting of populations and species on the plane defined by the 1 st and 4 th axes ( 37 per cent of total variability) clearly discriminate distinct lineages within the obscura species group.

Acknowledgements The field investigation in September 1984 benefited from the Kenyan Government support. Collecting permit in National Parks of Kenya was kindly made available by the Director of the Department of Wild Life in Nairobi. The following persons from the National Museum of Kenya in Nairobi generously provided assistance: Dr R. E. Leakey, Director Chief Executive, Dr J. Mark Ritchie, Head of Entomology Section; we are especially indebted to Miss C. Kabuye, Head of East African Herborium, for plant identification. Thanks are also due to Prof. G. K. Kinoti, Zoology Department, University of Nairobi and DrT. Odhiambo, Director of the International Centre of Insect Physiology and Ecology (ICIPE). D. madeirensis and $D$. guanche were kindly provided by Prof. A. Prevosti. We thank Miss N. Groseille for expert technical assistance in electrophoresis and maintaining strains successfully, J. P. Gauthier for computer assistance. Financial support for this research was provided by the Centre National de la Recherche Scientifique and a Franco-Hellenic grant to C. Krimbas and M. L. Cariou.

\section{REFERENCES}

ARAMBourg, C., CHAPPUis, P. A. AND JEANNEL, R. 1935. Mission scientifique de l'Omo: Itinéraire et liste des stations. Mém. Mus. Nat. Hist. Nat. (N.S.), 2, Fasc. 1, 1-22.
AYALA, F., POWELL, J. R., TRACEY, M. L., MOURAO, C. A. AND PEREZ-SALAS, S. 1972. Enzyme variability in the Drosophila willistoni group. III. Genic variation in natural populations of Drosophila willistoni. Genetics, 70, 113-139.

BOCK, I. R. 1980. Current status of the Drosophila melanogaster species group (Diptera). Syst. Entomol, 5, 341-356.

BOCK, I. R. AND WHEELER, M. R. 1972. The Drosophila melanogaster species group. Univ. Tex. Publ., 7213, 1-102.

Buzzati-traverso, A. A. AND SCOSSIROLI, R. E. 1955. The "obscura group" of the genus Drosophila. Advances in Genetics, 7, 47-92.

CABRERA, V. M., GONZALEZ, A. M. AND GULLON, A. 1980. Enzymatic polymorphism in Drosophila subobscura populations from the Canary Islands. Evolution, 34, 875-887.

CABRERA, v. M., GONZALEZ, A. M., LARRUGA, J. M. AND GULLON, A. 1983. Genetic distance and evolutionary relationships in the Drosophila obscura group. Evolution, 37, 675-689.

CARSON, H. L. 1951. Breeding sites of Drosophila pseudoobscura and Drosophila persimilis in the transition zone of the Sierra Nevada. Evolution, 5, 91-96.

CARSON, H. L., KRIMBAS, C. B. AND LOUKAS, M. 1985. Slime fluxes, a larval niche of Drosophila subobscura. Col. Biologia Gallo-Hellenica, 10, 319-321.

DAINOU, O., CARIOU, M. L., DAVID, J. R. AND HICKEY, D. 1987. Amylase gene duplication: an ancestral trait in the Drosophila melanogaster species subgroup. Heredity, 59, 245-251. 
FARRIS, J. S. 1972. Estimating phylogenetic trees from distance matrices. Am. Nat., 106, 158-160.

FITCH, W. M. AND MARGOLIASH, E. 1967. Construction of phylogenetic trees. Science, 155, 276-284.

GORDON, C. 1942. Natural Breeding sites of Drosophila obscura. Nature (London), 149, 499

HAMILTON, A. C. AND PERRoTt, R. A. 1981. A study of altitudinal zonation in the montane forest belt of Mt. Elgon, Kenya/Uganda. Vegetatio, 45, 107-125.

KING, B. C. AND CHAPMAN, G. R. 1972. Volcanism of the Kenya rift valley. Phil. Trans. R. Soc. Lond. A., 271, 185-208.

KOSKE, T. 1953. Artkreuzungsversuche in der obscura-Gruppe der Gattung Drosophila. Z. indukt. Abstamm. Vererbungsl., $85,373-381$.

K RIMBAS, C. B. AND LOUKAS, M. 1984. Evolution of the obscura group Drosophila species. I. Salivary chromosomes and quantitative characters in D. subobscura and two closely related species. Heredity, 53, 469-482.

KRIMBAS, C. B. AND SOURDIS, J. 1987. Recent improvements in handling allelic isozymes data for tree construction. In Rattazzi, M. C., Scandalios, J. G. and Whitt, G. S. (eds) Isozymes: Current Topics in Biological and Medical Research. Vol. 15: Genetics, development and Evolution, Alan R. Riss, New York, pp. 49-62.

LAKovaARA, S. AND KerANEN, L. 1980. Phylogeny of the Drosophila obscura group. Genetika, 12, 157-172.

LAKOVAARA, S. AND SAURA, A. $1971 a$. Genetic variation in natural populations of Drosophila obscura. Genetics, 69, 377-384.

LAKOVAARA, S. AND SAURA, A. $1971 b$. Genic variation in marginal populations of Drosophila subobscura. Hereditas, $69,77-82$.

LAKOVAARA, S. AND SAURA, A. 1982. Evolution and speciation in the Drosophila obscura group: In Ashburner, M., Carson, H. L. and Thompson, J. N. Jr. (eds.) Genetics and Biology of Drosophila, Vol. 3b, Academic Press, New York, London, pp. 1-59.

LAKOVAARA, S., SAURA, A. AND FALK, C. T. 1972. Genetic distance and evolutionary relationships in the Drosophila obscura group. Evolution, 26, 177-184.

LAKOVAARA, S., SAURA, A., LANKINEN, P., POHJOLA, L. AND LOKKI, J. 1976. The use of isoenzymes in tracing evolution and classifying Drosophilidae. Zool. Scripta, 5, 173-179.

LANKINEN, P. AND PINSKER, W. 1977. Allozyme constitution of two standard strains of Drosophila subobscura. Experientia, 33, 1301-1302.

LARRUGA, J. M., CABRERA, V. M., GONZALEZ, A. M. AND GULlON, A. 1983. Molecular and chromosomal polymorphism in continental and insular populations from the southwestern range of Drosophila subobscura. Genetica, 60 , 191-205.

LEFEBVRE, J. 1976. Introduction aux analyses statistiques multidimensionnelles. Masson (ed.). Paris.

LEMEUNIER, F., TSACAS, L., DAVID, J. R. AND ASHBURNER, M. 1986. The melanogaster species group, In Ashburner, M., Thompson, J. N. Jr. and Carson, H. L. (eds.) The Genetics and Biology of Drosophila, Vol, 3e, Academic Press, London, pp. 147-256.

LOUKAS, M., KRIMBAS, C. B., MAVRAGANI-TSIPIDOU, P. AND KASTRITSIS, C. D. 1979. The genetics of allozyme loci in Drosophila subobscura and its photographic chromosome maps. J. Hered., 70, 17-26.
LOUKAS, M., KRIMBAS, C. B. AND VERGINI, Y. 1984. Evolution of the obscura group Drosophila species. II. Phylogeny of ten species based on electrophoretic data. Heredity, 53, 483-493.

MARINKOVIC, D., AYALA, F. J. AND ANDJELKoviC, M. 1978. Genetic polymorphism and phylogeny of Drosophila subobscura. Evolution, 32, 164-173.

PATTERSON, J. P. AND STONE, W. S. 1952. Evolution in the genus Drosophila, Macmillan, New York.

PINSKER, W. AND SPERLICH, D. 1979. Allozyme variation in natural populations of Drosophila subobscura along a north-south gradient. Genetica, 50, 207-219.

PINSKER, W. AND BURUGA, J. 1982. Comparative study of allozyme variation in six species of the Drosophila obscura group. Z. Zool. Syst. Evol.-Forsch, 20, 53-63.

PRAKASH, S. 1977. Genetic divergence in closely related sibling species Drosophila pseudoobscura, Drosophila persimilis and Drosophila miranda. Evolution, 31, 14-23.

PREvosti, A. 1959. Natural breeding site for D. ambigua. Dros. Inf. Serv., 33, 154.

SAURA, A. 1974. Genic variation in Scandinavian populations of Drosophila bifasciata. Hereditas, 76, 161-172.

SAURA, A., LAKOVAARA, S., LOKK I, J. AND LANKINEN, P. 1973. Genic variation in central and marginal populations of Drosophila subobscura. Hereditas, 75, 33-46.

SCHNELL, R. 1977. Introduction à la phytogéographie des pays tropicaux. 4(2). La flore et la végétation de l'Afrique tropicale. Gauthier-Villars, Paris.

SEGUY, E. 1938. Diptera. I. Nematocera et Brachycera, In Jeannel, R. (ed.) Mission scientifique de l'Omo, tome IV, Zoologie, Mus. Nat. Hist. Nat. Paris, pp. 319-380.

SHAW, C. R. AND PRASAD, R. 1970. Starch gel electrophoresis of enzymes. A compilation of recipes. Biochem. Genetics, 4, 297-320.

SNEATH, P. H. A. AND SOKAL, R. R. 1973. Numerical taxonomy, W. H. Freeman, San Francisco.

SOURDIS, J. AND KRIMBAS, C. B. 1987. Accuracy of phylogenetic trees estimated from DNA sequence data. $\mathrm{Mol}$. Biol. and Evol., 4, 159-166.

TATENO, Y., NEI, M. AND TAJIMA, F. 1982. Accuracy of estimated phylogenetic trees from molecular data. I. Distantly related species. J. Mol, Evol., 18, 387-404.

TSACAS, L. 1974. Drosophila matilei, nouvelle espèce de l'Ouest Cameroun du groupe melanogaster et redescription de $D$. microlabis Séguy (Diptera: Drosophilidae). Bull. Soc. ent Fr., 79, 149-151.

TSACAS, L. 1984. Nouvelles données sur la biogéographie et l'évolution du groupe Drosophila melanogaster en Afrique. Description de six nouvelles espèces (Diptera, Drosophilidae). Annls Soc. Ent. Fr. (N.S.)., 20, 419-438.

TSACAS, L., CARIOU, M. L. AND LACHAISE, D. 1985. Le groupe Drosophila obscura en Afrique de l'Est. Description de trois nouvelles espèces (Diptera, Drosophilidae). Annls. Soc. ent. Fr. (N.S.), 21, 413-424.

THROCKMORTON, L. H. 1975. The phylogeny, ecology and geography of Drosophila. King, R. C. (ed.) In Handbook of Genetics, Vol. 3, Plenum Press, N.Y., pp. 421-469.

WHEELER, M. R. 1981. The Drosophilidae: A taxonomic overview. In Ashburner, M., Carson, H. L. and Thompson, J. N. Jr. (eds.) Genetics and Biology of Drosophila, Vol. 3a, Academic Press, New York, London. pp. 1-97. 